\title{
Эффективность системы государственной поддержки региональных инвестиционных проектов на Дальнем Востоке России
}

\section{Артемий Филатов}

Российский экономический университет имени Г.В. Плеханова, Москва, Россия

\author{
Информация о статье \\ Поступила в редакцию: \\ 02.07.2020 \\ Принята \\ к опубликованию: \\ 18.08.2020 \\ УДК 332.1 \\ JEL R19
}

\begin{abstract}
Ключевые слова:
региональный инвестиционный проект, государственная поддержка инвестиций, система государственной поддержки, эффективность системы поддержки, пространственная дифференциация, опережающий рост, Дальневосточный федеральный округ
\end{abstract}

\section{Keywords:}

regional investment project, state support of investments, state support system, support system effectiveness, spatial differentiation, outpacing growth, Russian Far East

\begin{abstract}
Аннотация
В статье приведено понятие регионального инвестиционного проекта (далее - РИП) как инструмента реализации региональной инвестиционной политики. Проанализирован международной опьтт реализации региональной инвестиционной политики. Приведен анализ нормативно-правовой базы, регламентирующей государственную поддержку РИП в Дальневосточном федеральном округе, на основании которого идентифицирована система государственной поддержки. Выявлены противоречия в составе элементов системы. В результате проведенной оценки выявлена недостаточная эффективность функционирования системы.
\end{abstract}

The Effectiveness of the State Support System for Regional Investment Projects in the Russian Far East

Artemiy Filatov

\section{Abstract}

The article describes the concept of a regional investment project $(R I P)$. Regional investment projects are created in accordance with the regional development strategy. They are the instruments for the regional investment policy implementation in a country of the federal structure. Those projects significantly impact on the socio-economic indicators of the region. The international experience of the regional investment policy implementation was analyzed. This policy is aimed at reducing spatial differentiation. The Russian Far East regions require support for the regional investment projects to ensure the advanced socio-economic development in accordance with the Federal government priorities.

The effectiveness of the state support system is important for the RIPs. The structure of this system was identified and analyzed in the article. As a result of the analysis the contradictions in the composition of the system elements were found. At the federal level, there is no unified approach to identifying the ways to achieve the goals of the Russian Far East socio-economic 
development. Besides, contradictions were defined between the organizations providing the RIP support.

The support system effectiveness was estimated quantitatively. The performance of the individual RIPs was assessed at the first stage. The regional investment management efficiency was estimated at the second stage. As a result of the estimation, it was found that the system was not functioning efficiently and that the current configuration of the RIP support system didn't allow achieving the advanced socio-economic development of the Russian Far East regions.

\section{Введение}

Современные парадигмы экономического развития формируют вектор, основанный на усилении глобальной интеграции рыночного пространства. При этом данная парадигма несет в себе ряд рисков для развивающихся и богатых ресурсами стран. Возможность превращения таких государств в сырьевой придаток более развитых государств вызывает необходимость проведения структурных преобразований в экономике.

Основным двигателем структурных экономических преобразований являются инвестиции. Инвестиции по своей сущности способны не только количественно, на и качественно расширить производственный потенциал. Благодаря осуществлению инвестиций в научные исследования и разработки обеспечивается развитие новых отраслей, повышается удельная добавленная стоимость производимой продукции, оптимизируется производство и, таким образом, обеспечивается структурный переход экономики в качественно новое состояние.

В современной экономической ситуации, сложившейся в том числе и в Российской Федерации, негосударственные экономические агенты принимают решения об инвестициях автономно. Государство может директивно формировать инвестиционные потоки только в отношении бюджетных затрат и затрат государственных корпораций. Особую актуальность директивные меры приобретают, когда принимается решение о реализации долгосрочных проектов, важных для общеэкономического развития. Частные инвесторы принимают решение об инвестировании, исходя из показателей коммерческой эффективности. При этом инвесторы чаще распределяют финансовые ресурсы в пользу кратко- и среднесрочных инвестиционных проектов в силу высокой неопределенности в отношении будущей экономической ситуации. В этой связи особую актуальность приобретает вопрос поиска оптимального баланса между государственными и частными интересами.

Инструментом государственной инвестиционной политики, стимулирующей распределение инвестиций в соответствии с вектором социальноэкономического развития, является государственная поддержка инвестиционных проектов. В современной практике используется широкий спектр инструментов государственной поддержки, в том числе финансовые, имущественные и организационные инструменты [1].

Федеративная форма государственного устройства России диктует свои условия для осуществления поддержки инвестиционных проектов. Меры поддержки могут осуществлять как региональные, так и федеральные органы власти. При этом основные направления инвестиционной политики формируются федеральным центром, а на региональном уровне формируются инве- 
стиционные стратегии, целью которых является создание инвестиционного климата, повышение конкурентоспособности и эффективности экономики, что позволяет достигать поставленные перед регионом цели социальноэкономического развития [2].

Основной интерес региональных властей заключается в акселерации инвестиционной активности на своей территории. Устанавливая различные меры поддержки, регионы создают дополнительные конкурентные условия для инвестиций, конкурируя за их размещение на своей территории. Федеральные власти, устанавливая и финансируя меры поддержки инвестиционных проектов, нацелены на обеспечение опережающего экономического роста в отстающих регионах и снижение пространственной дифференциации [3].

Подобная региональная инвестиционная политика проводится федеральными властями в таких государствах, как КНР, США, Канада и ФРГ. В данных странах действуют специальные режимы, стимулирующие приток инвестиций для акселерации социально-экономического развития отдельных регионов. В КНР широкое распространение получили особые экономические зоны, предоставляющие резидентам налоговые и административные преференции [4]. Государственная корпорация «Долина реки Теннеси» в США, используя ряд инструментов, в том числе удержание цен на электроэнергию, оказывает содействие социально-экономическому развитию отдельных районов, расположенных вдоль реки Теннеси [5]. Федеральные и региональные власти Канады реализуют программу, нацеленную на развитие северных регионов страны за счет привлечения туда инвестиций, при этом основным инструментом выступает строительство инфраструктуры [6]. Опыт ФРГ демонстрирует, что в стране используются меры поддержки отдельных инвестиционных проектов в регионах, при этом отбор проектов осуществляется региональными властями, а финансирование - федеральными [7].

Приведенный международный опыт демонстрирует, что объектом реализации инвестиционной политики в федеративном государстве чаще всего выступают РИП. Они являются проектами, реализуемыми в соответствии со стратегией социально-экономического развития и способными оказать существенное влияние на развитие экономической и социальной сфер региона. Реализация РИП позволяет обеспечить задачи государственных органов в рамках наращивания валового регионального продукта, создания рабочих мест и расширения регионального бюджета. При этом, как отмечают некоторые авторы, РИП должны быть максимально адаптированы к социальноэкономической среде и особенностям конкретного региона [8].

Стимулирование притока инвестиций и поддержка реализации региональных инвестиционных проектов в Дальневосточном федеральном округе является важной повесткой федеральных органов власти Российской Федерации. Наращивание инвестиционной активности позволяет реализовать ключевой приоритет политики в отношении макрорегиона - обеспечение опережающих темпов социально-экономического развития.

Для целей привлечения инвестиций в регионы Дальневосточного федерального округа запущен ряд механизмов государственной поддержки инвестиционных проектов на федеральном уровне. При этом механизмы сформи- 
рованы в соответствии с различными документами стратегического развития, осуществляются различными субъектами и предполагают различные формы поддержки. Перечисленные факторы формируют систему государственной поддержки. Вопрос состоятельности данной системы определяет эффективность ее функционирования в условиях ограниченных ресурсов государственного бюджета.

Изучению вопросов относительно методов и эффективности управления РИП посвящено множество работ российских авторов. В работе Е.А. Гончаровой обоснован ключевой параметр РИП - соответствие стратегии социально-экономического развития региона [9]. При этом акцент сделан на том, что финансирование мер государственной поддержки РИП должно осуществляться из регионального бюджета. Необходимо отметить, что, с учетом приоритетности развития Дальневосточного федерального округа в повестке федеральных властей, сущность поддержки РИП приобретает иной характер, нацеленный на сглаживание пространственной дифференциации регионов.

К.Е. Азжеурова предлагает осуществление институциональных изменений в части субъектов управления региональными инвестиционными проектами на уровне субъекта Российской Федерации - изменение организационно-функциональной структуры комитета, ответственного за оценку эффективности и отбор РИП [10]. В данной работе возникает такой элемент системы управления РИП как субъекты. Однако стоит учесть, что в данной также предполагается поддержка РИП на региональном уровне для акселерации социально-экономического развития экономики региона.

Д.П. Малышев предлагает оценку эффективности региональными инвестиционными проектами в субъектах Российской Федерации на основе двух взаимодополняющих моделей - аддитивной модели, включающей в себя оценку некоторых макроэкономических параметров, и модели, отражающей вклад прироста инвестиций в прирост валового регионального продукта [11]. Модель демонстрирует различие в эффективности управления региональными инвестиционными проектами в субъектах Северо-Западного федерального округа. Среди недостатков данной методики следует отметить малое количество параметров и отсутствие бенчмаркинга при сравнении значений показателей.

Таким образом, несмотря на то, что вопрос оценки эффективности управления региональными инвестиционными проектами рассмотрен авторами достаточно подробно, в указанных работах проводится недостаточно системный анализ. Это заключается в том, что проводится оценка деятельности системы, но вопрос номинальной эффективности самой системы не раскрыт в полной мере. Более того, авторами не проведен анализ конкретных региональных инвестиционных проектов на предмет их реализации.

Таким образом, данное исследование призвано устранить методические пробелы в части системного анализа и эффективности системы государственной поддержки региональных инвестиционных проектов, нацеленной на снижение пространственной дифференции в Российской Федерации. Исследование выполнено на материалах Дальневосточного федерального округа, развитие которого стимулируется за счет широкого перечня механизмов поддержки инвестиционных проектов. 
Целью исследования является оценка эффективности действующей системы государственной поддержки региональных инвестиционных проектов в Дальневосточном федеральном округе.

Для достижения поставленной цели необходимо выполнить следующие задачи:

- проанализировать нормативно-правовую базу в части реализации региональной социально-экономической и инвестиционной политики в Дальневосточном федеральном округе;

- проанализировать такие элементы государственной поддержки региональных инвестиционных проектов как цели, задачи, объекты, принципы и субъекты;

- провести анализ качества фактической реализации региональных инвестиционных проектов в субъектах Дальневосточного федерального округа;

- предложить методику и оценить качество управления региональных инвестиционными проектами на региональном уровне.

Объектом настоящего исследования выступает система государственной поддержки региональных инвестиционных проектов как совокупность организационно-правовых и экономических отношений, сформированная на основе нормативно-правовых документов, определяющих направления реализации региональной социально-экономической и инвестиционной политики в субъектах Дальневосточного федерального округа.

В ходе проведения исследования применены общенаучные подходы, такие как логический, системный и процессный. Использованы методы обобщения, систематизации, классификации, анализа и синтеза. Исследование проведено на теоретических, методологических и нормативно-правовых материалах.

\section{Стратегия развития Дальнего Востока}

Определение структуры системы государственной поддержки региональных инвестиционных проектов в Дальневосточном федеральном округе (далее - ДФО) следует начать с анализа федеральных нормативных документов, задающих вектор социально-экономического развития субъектов, входящих в ДФО. Актуальность данного подхода объясняется необходимостью вовлечения ресурсов федерального центра и тем, что сущность региональных инвестиционных проектов предполагает их соответствие стратегии социально-экономического развития. При этом стратегию развития округа необходимо рассмотреть через призму приоритетов социально-экономического развития Российской Федерации.

Основным документом, формирующим приоритеты социальноэкономического развития Российской Федерации, является Указ Президента о национальных целях до 2024 года (далее - Указ о национальных целях). Документ устанавливает цели социально-экономического развития страны, которых необходимо добиться к 2024 г. [12]. Достижение поставленных целей позволит реализовать три основных приоритета социальноэкономического развития: обеспечение экономического роста, формирование комфортной среды для жизни и развитие человеческого капитала. 
Общие направления пространственного развития Российской Федерации отражены в Указе Президента «Об утверждении основ государственной политики регионального развития Российской Федерации на период до 2025 г.». Согласно данному документу, разработка и реализация политики регионального развития опирается на особенности территориального устройства, дифференциацию в уровне социально-экономического развития регионов, а также региональную специфику развития.

Исходя из основ государственной политики регионального развития сформирована Стратегия пространственного развития Российской Федерации. Стратегия направлена на обеспечение устойчивого и сбалансированного пространственного развития страны [13]. Ключевым приоритетом стратегии является снижение уровня дифференциации в экономическом развитии регионов.

На уровне ДФО действует стратегия социально-экономического развития. В стратегии заданы четыре вектора развития макрорегиона: развитие инфраструктуры, развитие субъектов Российской Федерации, развитие базовых отраслей экономики и развитие приграничного сотрудничества [14]. В документе отдельно выделены ключевые инвестиционные проекты.

Также в макрорегионе действует государственная программа развития Дальневосточного федерального округа [15]. Данная программа ориентирована на финансирование создания инфраструктуры, необходимой для привлечения инвестиций. За счет привлечения инвестиций будут достигнуты основные цели социально-экономического развития.

На основе анализа нормативно-правовой базы, регламентирующей пространственное и социально-экономическое Дальневосточного федерального округа, представляется возможным проведение систематизации и сравнительного анализа целей (табл. 1), которые должны лечь в основу формирования региональных инвестиционных проектов в регионе.

Таблийа 1

Систематизация целей социально-экономического развития Дальнего Востока

\begin{tabular}{|l|c|c|c|c|}
\hline \multirow{2}{*}{\multicolumn{1}{|c|}{ Группа целей }} & \multicolumn{4}{|c|}{ Количество целей в группе } \\
\cline { 2 - 5 } & $\begin{array}{c}\text { Указ } \\
\text { оациональ- } \\
\text { ных целях }\end{array}$ & $\begin{array}{c}\text { Стратегия про- } \\
\text { странственного } \\
\text { развития }\end{array}$ & $\begin{array}{c}\text { Стратегия раз- } \\
\text { вития ДФО }\end{array}$ & $\begin{array}{c}\text { Программа } \\
\text { ДФО }\end{array}$ \\
\hline Инновации & 2 & 1 & - & 1 \\
\hline $\begin{array}{l}\text { Опережающий рост } \\
\text { экономики }\end{array}$ & 1 & 1 & 1 & - \\
\hline Развитие экспорта & 1 & - & - & 2 \\
\hline Человеческий капитал & 2 & 1 & 1 & 1 \\
\hline $\begin{array}{l}\text { Комфортная среда для } \\
\text { жизни }\end{array}$ & 3 & 1 & - & - \\
\hline Обороноспособность & - & 1 & 1 & 2 \\
\hline
\end{tabular}

Источник: составлено автором

Из результатов проведенного анализа видно, что в настоящий момент на федеральном уровне существуют одно критичное различие в целеполага- 
нии при формировании концепций социально-экономического для России и Дальнего Востока - развитие инноваций и соответствующей инновационной среды как на федеральном, так и на региональном уровне. В системе целей стратегии и программы развития Дальневосточного федерального округа отсутствуют повестка о необходимости развития инновационной среды.

Во всех рассмотренных документах однозначно определены такие направления как обеспечение опережающего экономического роста, формирование комфортной городской среды и развитие человеческого капитала. Важно отметить, что последнее из перечисленных направлений является не только критичной целью для закрепления населения на территории Дальнего Востока, но и для обеспечения инновационного развития.

Далее необходимо провести анализ задач, направленных на достижение поставленных целей (табл. 2). Результатом данной процедуры является выявление дифференцированных подходов к достижению поставленных в стратегических документах целей.

Таблииа 2

Систематизация задач социально-экономического развития Дальнего Востока

\begin{tabular}{|c|c|c|c|c|}
\hline \multirow[b]{2}{*}{ Группа задач } & \multicolumn{4}{|c|}{ Количество задач в группе } \\
\hline & $\begin{array}{c}\text { Указ о нацио- } \\
\text { нальньхх це- } \\
\text { лях }\end{array}$ & $\begin{array}{c}\text { Стратегия про- } \\
\text { странственного } \\
\text { развития }\end{array}$ & $\begin{array}{c}\text { Стратегия } \\
\text { развития } \\
\text { ДФО } \\
\end{array}$ & $\begin{array}{c}\text { Программа } \\
\text { развития } \\
\text { ДФО } \\
\end{array}$ \\
\hline Социальная инфраструктура & 4 & 1 & 1 & 1 \\
\hline Комфортное жилье & 2 & 1 & 1 & - \\
\hline $\begin{array}{l}\text { Транспортная и инженерная } \\
\text { инфраструктура }\end{array}$ & 2 & 1 & - & 1 \\
\hline $\begin{array}{l}\text { Развитие отраслей специали- } \\
\text { зации }\end{array}$ & - & 1 & 1 & - \\
\hline $\begin{array}{l}\text { Межрегиональная коопера- } \\
\text { ция }\end{array}$ & - & 1 & 1 & - \\
\hline Развитие научной сферы & 1 & 1 & - & - \\
\hline Экспорт & 1 & - & - & 1 \\
\hline Экономические преференции & - & - & - & 1 \\
\hline $\begin{array}{l}\text { Обеспечение трудовых ре- } \\
\text { сурсов }\end{array}$ & - & - & 1 & - \\
\hline $\begin{array}{l}\text { Развитие конкурентоспособ- } \\
\text { ности продукции }\end{array}$ & - & - & 1 & - \\
\hline Привлечение инвестиций & - & - & - & 1 \\
\hline $\begin{array}{l}\text { Поддержка } \\
\text { народов }\end{array}$ & - & - & 1 & - \\
\hline Развитие базовых отраслей & - & 1 & - & - \\
\hline Малый и средний бизнес & 1 & - & - & - \\
\hline Цифровая экономика & 1 & - & - & - \\
\hline Производительность труда & 1 & - & - & - \\
\hline $\begin{array}{l}\text { Развитие геостратегических } \\
\text { территорий }\end{array}$ & - & 1 & - & - \\
\hline
\end{tabular}

Источник: составлено автором 
На основании анализа выявлено, что в документах допущен ряд существенных отличий в части достижения экономических показателей развития. Задачи, отраженные в стратегии и программе развития ДФО, не включают в себя развитие инновационной среды. Также стоит отметить существенную разницу в определении источников роста экономики - пространственная стратегия и стратегия развития ДФО предусматривают интеграцию с экономическим пространством Российской Федерации, в то время как остальные документы ориентированы на развитие экспорта. Национальные цели и программа развития ДФО предусматривают мультиотраслевое развитие, то в других документах акцент делается на развитие отраслей специализации.

Таким образом, на основании проведенного анализа федеральных нормативных документов, регламентирующих стратегические аспекты социально-экономического развития региона, выявлен ряд противоречий.

\section{Механизмы поддержки РИП}

В ДФО действует широкий спектр механизмов государственной поддержки инвестиционных проектов. Одним из наиболее востребованных является механизм предоставления особых условий ведения хозяйственной деятельности резидентам Территорий опережающего социально-экономического развития (далее - ТОР). В рамках данного механизма сформирован перечень территорий, резидентам которых предоставляется три ключевых меры поддержки - строительство инфраструктуры, оптимизация налоговой нагрузки и снижение административного давления [16].

Также в макрорегионе действует механизм резидентства на территории свободного порта Владивосток. Инвесторы, реализующие инвестиционные проекты на данной территории, получают налоговые льготы и административные преференции [17].

В регионах Дальнего Востока и Забайкалья действует механизм предоставления налоговых преференций для региональных инвестиционных проектов [18]. При использовании данного механизма инвесторы получают льготы по налогу на прибыль. Отличительной чертой является отсутствие привязки к какой-либо локации, необходимо лишь резидентство в указанном регионе.

Еще одним важным механизмом поддержки РИП в Дальневосточном федеральном округе является механизм, основанный на осуществлении финансирования из федерального бюджета реконструкции, строительства и технологического присоединения к инженерной инфраструктуре [19].

Важным механизмом поддержки является предоставление проектного финансирования на льготных условиях. Оператором данного механизма выступает АО «Фонд развития Дальнего Востока» [20]. Данный механизм поддержки региональных инвестиционных проектов осуществляется в соответствии с государственной программой «Социально-экономическое развитие Дальневосточного федерального округа».

Инвесторы, реализующие инвестиционные проекты на Дальнем Востоке, могут также получить финансирование в рамках общероссийской «Программы поддержки инвестиционных проектов, реализуемых на территории Российской Федерации на основе проектного финансирования». Программа 
предполагает выдачу государственных гарантий для целей получения кредитов в финансовых организациях, направленных на реализацию инвестиционного проекта [21].

Важным с точки зрения стратегического развития региональных инвестиционных проектов выступает механизм фиксации регуляторной среды для инвестора [22]. В рамках механизма закрепляется размер федеральных налогов (за исключением косвенных) и взносов во внебюджетные фонды (за исключением Пенсионного фонда), а также действующие запретительные и ограничительные меры.

На уровне субъектов Дальневосточного федерального округа действуют законы, регламентирующие как общие направления инвестиционной политики, так и локальные меры государственной поддержки региональных инвестиционных проектов. Регионы имеют схожую систему государственной поддержки, предоставляя финансовые (налоговое стимулирование, субсидии, гарантии), имущественные (предоставление земельных участков) и организационные (продвижение и сопровождение проектов) меры поддержки.

\section{Анализ элементов системы}

Таким образом, на основании анализа стратегических документов, определены такие элементы системы государственной поддержки РИП как цели и задачи. Объекты, принципы и субъекты как элементы системы будут определены на основании анализа действующих механизмов поддержки.

Важным элементом системы государственной поддержки РИП в Дальневосточном федеральном округе являются объекты. Согласование целевых групп объектов в стратегических документах и механизмах поддержки обеспечивает эффективное расходование бюджетных ресурсов и повышает эффективность реализуемых проектов. Процедуру сравнения объектов возможно провести на основании сопоставления отраслей.

Таким образом, проведен анализ отраслей, обозначенных в федеральных и региональных стратегических документах, а также закрепленных в механизмах государственной поддержки на предмет их соответствия (табл. 3). Для этого объекты разделены на 3 группы: производственные отрасли, магистральная инфраструктура и социальная инфраструктура.

В анализе не учитывались отраслевые ограничения таких механизмов поддержки, как предоставление налоговых преференций для региональных инвестиционных проектов и резидентов свободного порта Владивосток [23], а также финансирование приоритетных проектов и проектов на основе проектного финансирования, так как они нацелены на общее повышение инвестиционного климата и не предъявляют существенных ограничений к отраслям - объектам региональных инвестиционных проектов.

На основании проведенного анализа получен вывод о том, что в большинстве случаев федеральные и региональные стратегические документы, а также механизмы поддержки инвестиционных проектов сфокусированы на идентичных отраслях, выступающими объектами РИП. 
Таблий 3

Систематизация объектов региональных инвестиционных проектов в Дальневосточном федеральном округе

\begin{tabular}{|c|c|c|c|c|c|}
\hline & $\begin{array}{c}\text { Указ о } \\
\text { националь- } \\
\text { ных целях }\end{array}$ & $\begin{array}{c}\text { Простран- } \\
\text { ственная стра- } \\
\text { тегия }\end{array}$ & $\begin{array}{l}\text { Страте- } \\
\text { гия } \\
\text { ДВФО }\end{array}$ & $\begin{array}{c}\text { Инвестицион- } \\
\text { ные стратегии } \\
\text { регионов } \\
\text { ДВФО } \\
\end{array}$ & $\begin{array}{c}\text { TOCЭ } \\
\mathbf{P}\end{array}$ \\
\hline \multicolumn{6}{|c|}{ Производственные отрасли } \\
\hline Машиностроение & $\checkmark$ & $\checkmark$ & $\checkmark$ & $\checkmark$ & $\checkmark$ \\
\hline $\begin{array}{ll}\text { Пищевое } \\
\text { водство }\end{array}$ & & $\checkmark$ & $\checkmark$ & $\checkmark$ & $\checkmark$ \\
\hline $\begin{array}{l}\text { Лесная промыш- } \\
\text { ленность }\end{array}$ & $\checkmark$ & $\checkmark$ & $\checkmark$ & $\checkmark$ & $\checkmark$ \\
\hline Металлургия & $\checkmark$ & $\checkmark$ & $\checkmark$ & $\checkmark$ & $\checkmark$ \\
\hline $\begin{array}{l}\text { Агропромышлен- } \\
\text { ный комплекс }\end{array}$ & $\checkmark$ & $\checkmark$ & $\checkmark$ & $\checkmark$ & $\checkmark$ \\
\hline $\begin{array}{l}\text { Наука и иннова- } \\
\text { ции }\end{array}$ & $\checkmark$ & $\checkmark$ & $\checkmark$ & $\checkmark$ & $\checkmark$ \\
\hline $\begin{array}{l}\text { Химическое про- } \\
\text { изводство }\end{array}$ & $\checkmark$ & $\checkmark$ & $\checkmark$ & $\checkmark$ & $\checkmark$ \\
\hline $\begin{array}{l}\text { Добыча полезных } \\
\text { ископаемых }\end{array}$ & & $\checkmark$ & $\checkmark$ & $\checkmark$ & $\checkmark$ \\
\hline $\begin{array}{l}\text { Транспортировка } \\
\text { и хранение }\end{array}$ & $\checkmark$ & $\checkmark$ & $\checkmark$ & $\checkmark$ & $\checkmark$ \\
\hline $\begin{array}{l}\text { Легкая промыш- } \\
\text { ленность }\end{array}$ & $\checkmark$ & $\checkmark$ & & & $\checkmark$ \\
\hline $\begin{array}{l}\text { Строительная } \\
\text { отрасль }\end{array}$ & $\checkmark$ & & $\checkmark$ & $\checkmark$ & $\checkmark$ \\
\hline $\begin{array}{l}\text { Малое и среднее } \\
\text { предприниматель- } \\
\text { ство }\end{array}$ & $\checkmark$ & & & $\checkmark$ & $\checkmark$ \\
\hline Туризм & & $\checkmark$ & $\checkmark$ & $\checkmark$ & $\checkmark$ \\
\hline $\begin{array}{l}\text { Нефтегазовая } \\
\text { промышленность }\end{array}$ & & $\checkmark$ & & $\checkmark$ & \\
\hline $\begin{array}{l}\text { Космический } \\
\text { центр }\end{array}$ & & & $\checkmark$ & & \\
\hline \multicolumn{6}{|c|}{ Магистральная инфраструктура } \\
\hline $\begin{array}{ll}\text { Инженерная } & \text { ин- } \\
\text { фраструктура }\end{array}$ & $\checkmark$ & $\checkmark$ & $\checkmark$ & $\checkmark$ & $\checkmark$ \\
\hline $\begin{array}{l}\text { Транспортная } \\
\text { инфраструктура }\end{array}$ & $\checkmark$ & $\checkmark$ & $\checkmark$ & & $\checkmark$ \\
\hline \multicolumn{6}{|c|}{ Социальная инфраструктура } \\
\hline $\begin{array}{ll}\text { Социальная } & \text { ин- } \\
\text { фраструктура } & \\
\end{array}$ & $\checkmark$ & & $\checkmark$ & $\checkmark$ & $\checkmark$ \\
\hline
\end{tabular}

Источник: составлено автором 
Анализ стратегических документов и механизмов поддержки позволяет выделить основные принципы государственной поддержки РИП в Дальневосточном федеральном округе:

- принцип ориентированности на реализацию стратегических целей региона и страны в целом;

- принцип преемственности уровней власти (федеральные меры поддержки директивно распространяются на региональные органы власти);

- принцип финансовой ответственности (субъекты имеют право самостоятельно вводить меры поддержки при финансировании за свой счет);

- принцип конкуренции (адресная поддержка предоставляется на конкурсной основе);

- принцип комплексности поддержки (инвестиционный проект может использовать несколько видов поддержки);

- принцип обязательного администрирования (для применения льгот и прочих видов поддержки необходимо согласование с органами власти).

Анализ субъектов, предоставляющих меры поддержки (рис. 1) демонстрирует наличие ряда противоречий. В частности, в рамках финансирования приоритетных инвестиционных проектов Фонд развития Дальнего Востока и Арктики является распорядителем финансовых ресурсов, при этом ответственность за достижение данных целевых показателей инвестиционных проектов, получающих финансирование, несет Министерство по развитию Дальнего Востока и Арктики.

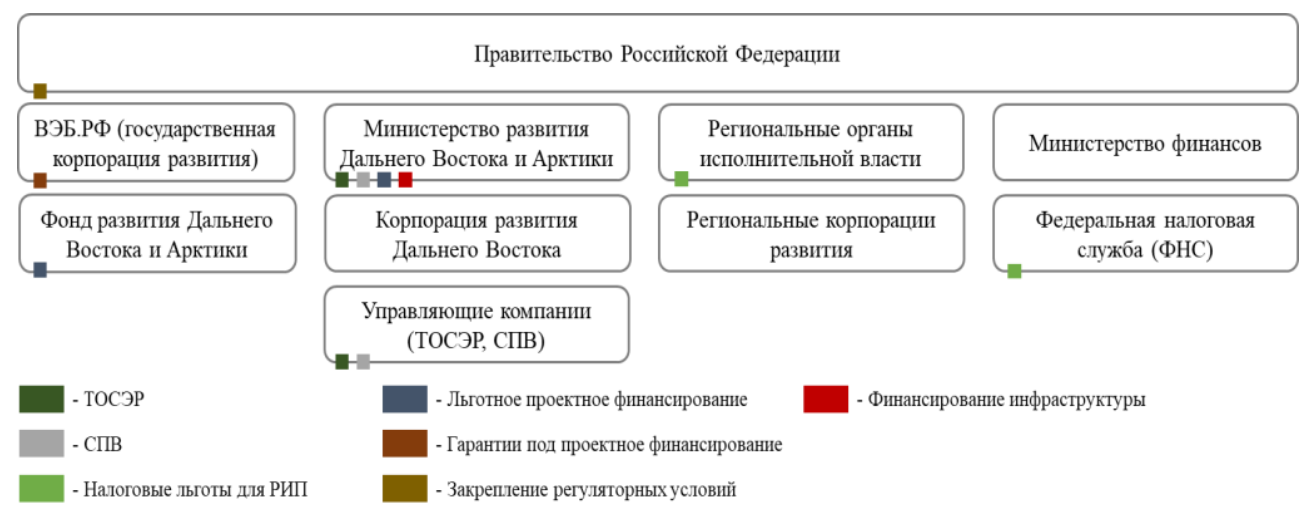

Puc. 1. Организационная структура субъектов, оказывающих государственную поддержку региональных инвестиционных проектов в Дальневосточном федеральном округе

Источник: составлено автором

Подобная ситуация наблюдается в механизме предоставления налоговых льгот для региональных инвестиционных проектов. Предоставление статуса регионального инвестиционного проекта осуществляется региональным органом исполнительной власти, в то время как его лишение осуществляется Налоговой службой. Потенциально данная конфигурация вызываем конфликт между экономической и бюджетной политикой регионов. 


\section{Оценка эффективности системы}

Выявленные противоречия в структуре элементов системы государственной поддержки РИП в Дальневосточном федеральном округе позволяет сформировать гипотезу о ее недостаточной эффективности. Для подтверждения данной гипотезы необходимо провести количественную оценку. Оценить эффективность работы системы предлагается на основе двухэтапной методики. На первом этапе будут проанализированы фактические результаты РИП, осуществленных с применением механизмов государственной поддержки. На втором этапе будет проведен анализ качества управления инвестициями на уровне субъектов, в входящих в Дальневосточный федеральный округ. Целью проводимой оценки является определение возможности действующей системы государственной поддержки РИП обеспечивать опережающие темпы социально-экономического развития регионов Дальнего Востока.

Для проведения оценки реализации региональных инвестиционных проектов проанализированы проекты, отобранные для осуществления государственной поддержки в рамках государственной программы «Социальноэкономическое развитие Дальневосточного федерального округа» со сроком окончания не позднее 2019 г. (табл. 4).

Полученная выборка состоит из 22 региональных инвестиционных проектов, общая сумма финансирования которых составляет 185 млрд руб. Важно отметить, что 73\% указанного объема финансирования приходится на металлургическую отрасль, в рамках которой планируется строительство горнообогатительных и горно-металлургических комбинатов. Реализация обозначенного перечня проектов позволяет создать более 4,5 тыс. рабочих.

В условиях дефицита информации анализ реализации указанных региональных инвестиционных проектов целесообразно провести на предмет соблюдения плановых сроков завершения реализации инвестиционной стадии данных проектов. Это связано с тем, что при планировании портфеля инвестиционных проектов, государство, как субъект, предоставляющий меры поддержки, заинтересовано в реализации проектов с наименьшими отклонениями для достижения планируемых показателей экономической, социальной и бюджетной эффективности.

Таблицча 4

Параметры региональных инвестиционных проектов, реализуемых в Дальневосточном федеральном округе с применением мер федеральной поддержки

\begin{tabular}{|c|c|c|c|c|c|c|}
\hline Регион & Наименование инвестиционного проекта & $\begin{array}{c}\text { Год } \\
\text { начала }\end{array}$ & $\begin{array}{c}\text { Год } \\
\text { окон- } \\
\text { чания }\end{array}$ & $\begin{array}{l}\text { Объем } \\
\text { финанси- } \\
\text { рования, } \\
\text { млн. руб. }\end{array}$ & $\begin{array}{l}\text { Кол-во } \\
\text { создавае- } \\
\text { мых рабо- } \\
\text { чих мест, } \\
\text { шт. }\end{array}$ & $\begin{array}{l}\text { Проект } \\
\text { запу- } \\
\text { щен в } \\
\text { срок }\end{array}$ \\
\hline 1 & 2 & 3 & 4 & 5 & 6 & 7 \\
\hline $\begin{array}{l}\text { Магадан- } \\
\text { ская } \\
\text { область }\end{array}$ & $\begin{array}{l}\text { Строительство горнодобывающего и перераба- } \\
\text { тывающего предприятия на базе Наталкинского } \\
\text { золоторудного месторождения }\end{array}$ & 2009 & 2019 & 88500 & 1000 & Да \\
\hline $\begin{array}{l}\text { Еврейская } \\
\text { автоном- } \\
\text { ная } \\
\text { область }\end{array}$ & $\begin{array}{l}\text { Строительство Кимкано-Сутарского горно- } \\
\text { обогатительного комбината на базе Кимканского } \\
\text { и Сутарского месторождений железистых квар- } \\
\text { цитов }\end{array}$ & 2008 & 2018 & 23613 & Нет данных & Да \\
\hline
\end{tabular}




\begin{tabular}{|c|c|c|c|c|c|c|}
\hline 1 & 2 & 3 & 4 & 5 & 6 & 7 \\
\hline $\begin{array}{l}\text { Амурская } \\
\text { область }\end{array}$ & $\begin{array}{l}\text { Создание производства метанола мощностью } 1 \\
\text { млн. тонн в год в г. Сковородино Амурской обл. } \\
\text { (с модернизацией объектов пункта подготовки и } \\
\text { пропарки вагонов) }\end{array}$ & 2016 & 2018 & 23400 & 150 & Нет \\
\hline $\begin{array}{l}\text { Камчат- } \\
\text { ский край }\end{array}$ & $\begin{array}{l}\text { Горно-металлургический комбинат по добыче и } \\
\text { переработке руды Озерновского золоторудного } \\
\text { месторождения Камчатского края }\end{array}$ & 2009 & 2018 & 15300 & 1200 & Да \\
\hline $\begin{array}{l}\text { Респуб- } \\
\text { лика Саха } \\
\text { (Якутия) }\end{array}$ & 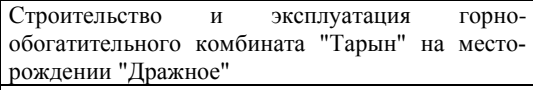 & 2016 & 2018 & 7444 & 375 & Да \\
\hline $\begin{array}{l}\text { Сахалин- } \\
\text { ская } \\
\text { область }\end{array}$ & $\begin{array}{l}\text { Строительство молочно-товарной фермы на } 1000 \\
\text { голов основного стада и агрогородка усадебного } \\
\text { типа на } 50 \text { дворов в с. Раздольное Корсаковского } \\
\text { района }\end{array}$ & 2015 & 2018 & 5733 & Нет данных & Да \\
\hline $\begin{array}{l}\text { Примор- } \\
\text { ский край }\end{array}$ & $\begin{array}{l}\text { Строительство морского терминала для перевал- } \\
\text { ки сжиженных углеводородных газов (СУГ) в } \\
\text { районе бухты Перевозной, Приморский край }\end{array}$ & 2016 & 2019 & 4500 & Нет данных & Нет \\
\hline $\begin{array}{l}\text { Камчат- } \\
\text { ский край }\end{array}$ & $\begin{array}{l}\text { Рыбоперерабатывающий завод в районе бывшего } \\
\text { с. Красное Карагинского района Камчатского } \\
\text { края }\end{array}$ & 2015 & 2018 & 2500 & 400 & Да \\
\hline $\begin{array}{l}\text { Сахалин- } \\
\text { ская } \\
\text { область }\end{array}$ & $\begin{array}{l}\text { Свиноводческий комплекс по производству } \\
62000 \text { голов в год в с. Таранай Анивского город- } \\
\text { ского округа Сахалинской области. II этап. } \\
\text { Свиноводческий комплекс на } 50000 \text { голов в год } \\
\end{array}$ & 2016 & 2018 & 2390 & 144 & Да \\
\hline $\begin{array}{l}\text { Респуб- } \\
\text { лика Саха } \\
\text { (Якутия) } \\
\end{array}$ & $\begin{array}{l}\text { Строительство круглогодичного тепличного } \\
\text { комплекса в с. Сырдах городского округа "Город } \\
\text { Якутск" } \\
\end{array}$ & 2016 & 2019 & 1745 & 63 & Да \\
\hline $\begin{array}{l}\text { Амурская } \\
\text { область }\end{array}$ & $\begin{array}{l}\text { Производственно- логистический комплекс } \\
\text { хранения растительного сырья с оборудованием } \\
\text { для подработки, сушки, перевалки зерна и } \\
\text { комплексный селекционно-семеноводческий } \\
\text { центр по производству семян сельскохозяй- } \\
\text { ственных культур (включая сою) } 20 \text { тыс. тонн }\end{array}$ & 2013 & 2019 & 1726 & 52 & Да \\
\hline $\begin{array}{l}\text { Камчат- } \\
\text { ский край }\end{array}$ & $\begin{array}{l}\text { Строительство тепличного комбината производ- } \\
\text { ственной площадью } 4,8 \text { га для выращивания } \\
\text { овощных культур в Камчатском крае, Елизов- } \\
\text { ский район, пос. Заречный }\end{array}$ & 2015 & 2018 & 1480 & 71 & Нет \\
\hline $\begin{array}{l}\text { Хабаров- } \\
\text { ский край }\end{array}$ & \begin{tabular}{|l|} 
Строительство свиноводческого комплекса по \\
производству до 70000 голов в год в Вяземском и \\
Хабаровском районах Хабаровского края \\
\end{tabular} & 2016 & 2018 & 1031 & Нет данных & Нет \\
\hline $\begin{array}{l}\text { Камчат- } \\
\text { ский край }\end{array}$ & Развитие свиноводства в Камчатском крае & 2010 & 2019 & 1000 & 168 & Да \\
\hline $\begin{array}{l}\text { Магадан- } \\
\text { ская } \\
\text { область }\end{array}$ & Тепличный комплекс "Агро Инвест" & 2015 & 2019 & 1000 & 75 & Нет \\
\hline $\begin{array}{l}\text { Камчат- } \\
\text { ский край }\end{array}$ & $\begin{array}{l}\text { Реконструкция и модернизация санаторно- } \\
\text { курортного комплекса Начикинский }\end{array}$ & 2013 & 2017 & 910 & Нет данных & Нет \\
\hline $\begin{array}{l}\text { Сахалин- } \\
\text { ская } \\
\text { область } \\
\end{array}$ & $\begin{array}{l}\text { Строительство мини-завода по производству } \\
\text { сжиженного природного газа }\end{array}$ & 2016 & 2017 & 836 & Нет данных & Нет \\
\hline $\begin{array}{l}\text { Сахалин- } \\
\text { ская } \\
\text { область }\end{array}$ & $\begin{array}{l}\text { Организация производства агара (пищевого и } \\
\text { микробиологического) }\end{array}$ & 2018 & 2019 & 800 & 70 & Нет \\
\hline $\begin{array}{l}\text { Камчат- } \\
\text { ский край }\end{array}$ & $\begin{array}{l}\text { Организация свиноводческого комплекса на } 550 \\
\text { продуктивных свиноматок в Камчатском крае }\end{array}$ & 2015 & 2017 & 798 & 93 & Нет \\
\hline $\begin{array}{l}\text { Камчат- } \\
\text { ский край }\end{array}$ & $\begin{array}{l}\text { Строительство и ввод в эксплуатацию комплекса } \\
\text { по хранению и складированию нефтепродуктов } \\
\text { емкостью } 18000 \text { тонн на базе существующего } \\
\text { причального сооружения в г. Петропавловске- } \\
\text { Камчатском }\end{array}$ & 2016 & 2019 & 460 & 382 & Нет \\
\hline $\begin{array}{l}\text { Респуб- } \\
\text { лика Саха } \\
\text { (Якутия) }\end{array}$ & $\begin{array}{l}\text { Модернизация кожевенно-обувного и мехового } \\
\text { производства, выпуск оленьей замши, производ- } \\
\text { ство коллагена из некондиционных шкур }\end{array}$ & 2018 & 2019 & 350 & 332 & Нет \\
\hline $\begin{array}{l}\text { Камчат- } \\
\text { ский край }\end{array}$ & $\begin{array}{l}\text { Организация тепличного хозяйства в Камчатском } \\
\text { крае }\end{array}$ & 2017 & 2018 & 320 & Нет данных & Нет \\
\hline
\end{tabular}

Источник: составлено автором

В результате выполненных аналитических процедур установлено, что только 10 из 22 РИП завершены в срок. Несмотря на то, что на успешно реа- 
лизованные проекты приходится $81 \%$ от совокупного объема инвестиций, такие проекты относятся к базовым секторам экономики.

Таким образом можно заключить, что власти при реализации прямого или косвенного участия в региональных инвестиционных проектах ориентированы на реализацию в первую очередь крупных проектов в базовых отраслях экономики. Данная политика имеет актуальность в краткосрочной перспективе, однако она не ориентирована на долгосрочную стратегическую эффективность.

Для оценки качества управления инвестиционными проектами на региональном уровне предлагается методический подход, основанный на оценке регионов по критериям, сформированным из макроэкономических параметров. Для проведения указанной процедуры использованы относительные параметры, отражающие возможность создания базиса для качественного роста валового регионального продукта за счет распределения инвестиционных потоков путем реализации инвестиционной политики на региональном уровне. Иными словами, предложенная методика позволяет оценить то, насколько осуществленные в ретроспективе инвестиции в рамках реализации РИП позволят достичь устойчивого качественного экономического роста в будущем при выходе инвестиционных проектов в эксплуатационную стадию. Таким образом, акцент в методике сделан на оценку косвенного эффекта от инвестиций на региональную экономику. Дополнительно в методику введены параметры, отражающие вовлечение ресурсов региона, что позволяет оценить то, насколько рыночная ситуация в регионах позволяет осваивать инвестиционные потоки и формировать прямой эффект от инвестиций.

Критерии оценки распределены на 3 блока: объем инвестиций, качество инвестиций, вовлечение ресурсов региона. В рамках каждого блока сформированы критерии оценки и веса критериев (рис. 2). Наибольшие веса получили группы критериев, отражающие оценку будущего косвенного эффекта. Критерии в рамках группы распределены равномерно, однако наиболее важные по мнению автора критерии наделены большим весом.

1. Норма накопления основного капитала является важным показателем качества управления инвестициями на региональном уровне, представляя собой отношение объема инвестиций к валовому региональному продукту. Данный показатель позволяет определить объем инвестиций в масштабах экономики региона.

2. Физический прирост инвестиций представляет собой показатель, отражающий фактическое изменение объема инвестиций без учета влияния фактора индексов цен. Данный критерий является особенно актуальным в силу того, что ценовой фактор может оказывать существенное влияние на статистическое определение изменения объема инвестиций в регионе в силу изменения как монетарных, так и рыночных условий.

3. Критерий доля инвестищий, осуществленных без привлечения средств федерального бюджета позволяет оценить фактические инвестиционные возможности региона без привязки к финансированию со стороны федерального центра. Более того, данный показатель отражает возможные риски, с которым регион может столкнуться при потере данного источника финансирования региональных инвестиционных проектов. 


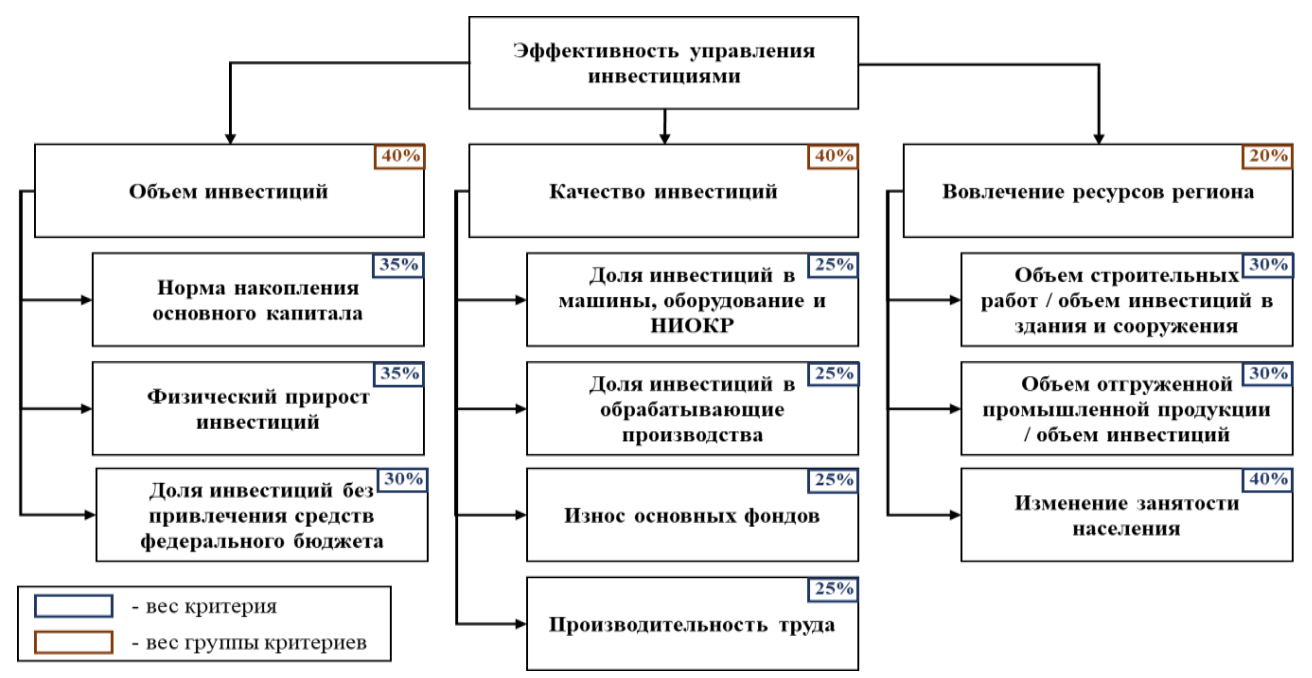

Puc. 2. Критерии оценки качества управления реальными инвестициями в регионах Источник: составлено автором Дальнего Востока

4. Доля инвестиций в машины, оборудование и НИОКР является критерием, позволяющим оценить объем инвестиций, который направляется в наиболее емкие с точки зрения будущего экономического эффекта объекты основных фондов. Инвестиции в здания и сооружения (магистральная инфраструктура, социальная инфраструктура и т.д.), несмотря на их весомый вклад в структуру объектов капитальных затрат, не позволяют напрямую оценить их эффективность.

5. Доля инвестиций в обрабатывающую промышленность. Данный критерий позволяет определить объем инвестиционных потоков, направляемых в наиболее перспективные отрасли экономики. Несмотря на то, что для регионов Дальнего Востока характерно преобладание в структуре ВРП таких видом деятельности как добыча полезных ископаемых, транспорт и торговля, структурные изменения вектора социально-экономического развития могут быть инициированы исключительно инвестированием в наиболее перспективные отрасли.

6. Износ основных фондов позволяет оценить качество инвестиций с точки зрения обновления и модернизации структуры основных фондов в регионе, что отражается на производственном потенциале региона. Для целей проведения оценки использован обратный показатель, равный отношению остаточной стоимости основных фондов к первоначальной.

7. Производительность труда включена в перечень критериев оценки эффективности управления инвестициями на региональном уровне в силу высокой актуальности, заключающейся в базовой предпосылке о том, что инвестиционный процесс тесно связан с формированием инвестиционной среды на региональном уровне, одной из целей которого является повышение эффективности экономики.

8. Отношение объема выполненных строительных работ к объему инвестиций в здания и сооружения позволяет оценить инвестиционную ем- 
кость региона. Данный критерий отражает объем капитальных затрат, формирующий прямой эффект от инвестиций, оказываемый на экономику. Чем выше данный показатель, тем выше степень влияния инвестиций на социально-экономическое развитие региона.

9. Отношение объема отгруженной продукции обрабатьвающих производств к объему инвестиций в машины и оборудование является критерием, аналогичным описанному выше. Для целей оценки регионов по данному критерию оценен объем отгруженных товаров в таких видах экономической деятельности, как «производство машин и оборудования», «производство компьютеров, электронных и оптических изделий; производство электрического оборудования».

10. Изменение занятости населения позволяет оценить степень влияния инвестиций на повышение занятости местного населения. Данный показатель является крайне важным с точки зрения социальных эффектов, одним из которых является рост занятости и денежных доходов населения. Показатель особенно актуален для регионов Дальневосточного федерального округа, одной из критических проблем которого является отток населения.

Оценка проведена путем сравнения значений каждого показателя по регионам Дальнего Востока со средним значением показателя по России. Для того, чтобы исключить влияние на оценку валового объема инвестиций в регионах, использованы относительные показатели. Значение по каждому критерию сформировано как среднее за 2010-2018 гг., взвешенное на валовый объем инвестиций в каждом году. Оценка каждому региону проставлена на основании 10-балльной шкалы (табл. 5). Логика балльной системы заключается в оценке уровня отклонения указанных макроэкономических параметров от среднего значения по Российской Федерации. Это позволяет оценить эффективность управления инвестициями в регионе с учетом экономических шоков, отражавшихся на экономике всей страны. Чем больше средневзвешенное отклонение параметров конкретного региона от среднероссийского значения, тем выше балл, и наоборот. В случае, если значения в регионах совпадают со среднероссийским показателем, региону проставляется оценка «5».

Таблица 5

Распределение оценок качества управления реальными инвестициями в регионах Дальнего Востока

\begin{tabular}{|c|c|c|}
\hline Нижняя граница отклонения, \% & Верхняя граница отклонения, \% & Оценка \\
\hline-100 & -80 & 1 \\
\hline-80 & -60 & 2 \\
\hline-60 & -40 & 3 \\
\hline-40 & -20 & 4 \\
\hline-20 & 0 & 5 \\
\hline 0 & 20 & 6 \\
\hline 20 & 40 & 7 \\
\hline 60 & 60 & 8 \\
\hline 80 & 80 & 9 \\
\hline
\end{tabular}

Источник: составлено автором 
Общие результаты оценки продемонстрировали, что в регионах Дальневосточного федерального округа не достигается уровень эффективности, соответствующий среднероссийскому уровню - средний итоговый балл составил 4,87 (табл. 6). Это позволяет сделать вывод о том, что инвестиционный потенциал для обеспечения опережающих темпов социальноэкономического развития не сформирован.

При этом, в регионах Дальнего Востока отмечены высокие значения нормы накопления основного капитала: совокупная средневзвешенная норма накопления в ДФО в 2018 г. составила 26,8\%, в России - 20,7\%. Также важной отличительной чертой регионов Дальнего Востока является низкий совокупный износ основных фондов - ДФО занимает 3 место по этому показателю среди всех федеральных округов России.

Таблица 6

Ранжирование регионов Дальневосточного федерального округа на основании интегральной оценки качества управления инвестициями

\begin{tabular}{|c|c|c|c|c|c|c|}
\hline & $\begin{array}{c}\text { Итого- } \\
\text { вый } \\
\text { балл }\end{array}$ & $\begin{array}{c}\text { Рейтинг, } \\
\text { Общая } \\
\text { оценка }\end{array}$ & $\begin{array}{l}\text { Рейтинг, } \\
\text { Группа } 1\end{array}$ & $\begin{array}{l}\text { Рейтинг, } \\
\text { Группа } 2\end{array}$ & $\begin{array}{l}\text { Рейтинг, } \\
\text { Группа } 3\end{array}$ & $\begin{array}{c}\text { Доля в объеме } \\
\text { инвестиций } \\
\text { ДФО (2010- } \\
2018), \% \\
\end{array}$ \\
\hline Амурская область & 5,57 & 1 & 1 & 5 & 7 & 12 \\
\hline Хабаровский край & 5,51 & 2 & 9 & 1 & 2 & 13 \\
\hline Приморский край & 5,27 & 3 & 7 & 2 & 3 & 16 \\
\hline Республика Бурятия & 5,10 & 4 & 10 & 3 & 1 & 4 \\
\hline Магаданская область & 5,01 & 5 & 2 & 8 & 6 & 3 \\
\hline $\begin{array}{l}\text { Республика Саха } \\
\text { (Якутия) }\end{array}$ & 4,75 & 6 & 4 & 9 & 5 & 22 \\
\hline Камчатский край & 4,68 & 7 & 11 & 4 & 4 & 3 \\
\hline Забайкальский край & 4,62 & 8 & 5 & 6 & 11 & 7 \\
\hline $\begin{array}{l}\text { Еврейская автоном- } \\
\text { ная область }\end{array}$ & 4,59 & 9 & 3 & 10 & 9 & 1 \\
\hline $\begin{array}{l}\text { Чукотский автоном- } \\
\text { ный округ }\end{array}$ & 4,42 & 10 & 8 & 7 & 8 & 1 \\
\hline Сахалинская область & 4,10 & 11 & 6 & 11 & 10 & 18 \\
\hline
\end{tabular}

Источник: составлено автором

Важно отметить, что пять крупнейших регионов ДФО, на которые суммарно приходится 81\% объема инвестиций, по результатам ранжирования распределились крайне неравномерно. Республика Саха (Якутия) и Сахалинская область, основу экономики которых составляет добыча полезных ископаемых расположись в ниже, чем Амурская область, Хабаровский и Приморский край, отличающихся более диверсифицированной структурой экономики.

Наивысшую оценку получила Амурская область. Регион отличается наиболее высокой нормой накопления основного капитала, наивысшим показателем физического прироста инвестиций в основной капитал, а также од- 
ним из наиболее высоких показателей объема инвестиций в обрабатывающую промышленность.

Такие регионы как Хабаровский и Приморский край демонстрируют наивысшие показатели доли инвестиций в обрабатывающие производства. Пиковые значения доли инвестиций в обрабатывающую промышленность в Хабаровском крае наблюдаются в 2012-2015 гг., что коррелирует с реализацией крупных региональных инвестиционных проектов, вошедших в перечень приоритетных и получивших федеральную поддержку.

В Приморском крае доля инвестиций в обрабатывающие производства выросла с 15,3\% до 23\% в 2015 г. одновременно с созданием территорий опережающего социально-экономического развития. При этом регион является лидером по количеству созданных ТОСЭР и количеству резидентов (117 резидентов в 2020 г.) [24].

\section{Выводы}

Таким образом, проведен анализа системы государственной поддержки региональных инвестиционных проектов в Дальневосточном округе. В результате идентифицированы ключевые элементы данной системы. Выявлено наличие некоторой несогласованности в части федеральных стратегически документов, нацеленных на реализацию опережающего социальноэкономического развития Дальневосточного федерального округа. В этой связи реализация государственной поддержки региональных инвестиционных проектов может не принести ожидаемых результатов.

Также определено, что в структуре субъектов, реализующих государственную поддержку региональных инвестиционных проектов также присутствует ряд несогласованностей, что потенциально мешает достижению плановых показателей социально экономического развития.

Проведенный на основании стратегических документов и документов, регламентирующих механизмы поддержки РИП, анализ позволил удостовериться в том, что в данных документах определены схожие отрасли, представляющие собой объекты РИП.

Анализ фактического исполнения региональных инвестиционных проектов продемонстрировал приоритетность в реализации крупных проектов в базовых секторах экономики. Такая политика не позволяет выйти макрорегиону на траекторию стабильного опережающего социально-экономического развития. Данный тезис подтвержден макроэкономическим анализом вклада реальных инвестиций в социально-экономическое развития Дальнего Востока. Согласно результатам данного анализа, качество управления инвестиционными потоками на региональном уровне не обеспечивает опережающих темпов социально-экономического роста.

Таким образом, на основании проведенного исследования, выявлены два ключевых фактора, снижающих эффективность системы государственной поддержки региональных инвестиционных проектов в Дальневосточном федеральном округе. Во-первых, выявлены разногласия в части целеполагания оказываемых мер поддержки и субъектов, непосредственно реализующих поддержку. Во-вторых, анализ исполнения региональных инвестиционных 
проектов позволил выявить нацеленность системы на поддержку наиболее крупных проектов, что не позволяет достигать опережающих темпов социально-экономического роста в долгосрочной перспективе.

\section{Список источников / References}

1. Филатов А.С. Качество государственной поддержки инвестиционных проектов как драйвер экономического роста. КАЧЕСТВО. ИННОВАЦИИ. ОБРАЗОВАНИЕ, 2018, № 2, cc. 56-61. [Filatov A.S. Kachestvo gosudarstvennoj podderzhki investicionnyh proektov kak drajver ekonomicheskogo rosta [The quality of government support for investment projects as a driver of economic growth] kachestvo. Innovacii. Obrazovanie = quality. Innovation. Education, 2018, № 2, pp. 56-61.]

2. Музыкаев Б. А.-Х. Реализация инвестиционных проектов как способ устойчивого развития региональной экономики. Государственный аудит. Право. Экономика, 2016, №. 2, cc. 188-190. [Muzykaev B. A.-H. Realizaciya investicionnyh proektov kak sposob ustojchivogo razvitiya regional'noj ekonomiki [Implementation of investment projects as a way of sustainable development of the regional economy] Gosudarstvennyj audit. Pravo. Ekonomika. = State audit. Law. The economy, 2016, №. 2, pp. 188-190.]

3. Седова Н.В. Основные направления и способы выравнивания уровня социальноэкономического развития регионов. Проблемы устойчивого развития российских регионов. Вып. 2015г., Тюмень, 2015, сc. 101-104. [Sedova N.V. Osnovnye napravleniya i sposoby vyravnivaniya urovnya social'no-ekonomicheskogo razvitiya regionov [The main priorities and ways to align the socio-economic development of the regions]. Problemy ustojchivogo razvitiya rossijskih regionov. 2015 [Problems of sustainable development of the Russian regions. 2015]. Tyumen', 2015, pp. 101-104.]

4. Иванов С.А. Особые экономические зоны в Китае: уроки для дальневосточной политики. Россия и АTP. 2014, № 4, cc. 129-141. [Ivanov S.A. Osobye ekonomicheskie zony v Kitae: uroki dlya dal'nevostochnoj politiki [Special economic zones in China: lessons for Far Eastern policy] Rossiya $i$ ATR $=$ Russia and Asia-Pacific region, 2014, № 4, pp. 129-141.]

5. Батманова В.В. Направления использования в регионах России американского опыта реализации комплексных программ регионального развития. Вестник Волгоградского государственного университета. 2014, № 3, сс. 93-103. [Batmanova V.V. Napravleniya ispol'zovaniya v regionah Rossii amerikanskogo opyta realizacii kompleksnyh programm regional'nogo razvitiya [Areas of application in the Russian regions of the US experience in implementing integrated regional development programs] Vestnik Volgogradskogo gosudarstvennogo universiteta $=$ Bulletin of Volgograd State University, 2014, № 3, pp. 93-103.]

6. Ломакина А.И. Северность и континентальность - две стороны общей транспортной проблемы в Канаде и России. Канадский ежегодник. 2016, № 20, сс. 287-314. [Lomakina A.I. Severnost' i kontinental'nost' - dve storony obshchej transportnoj problemy v Kanade i Rossii [Northern and Continental - two sides of the common transport problem in Canada and Russia] Kanadskij ezhegodnik = Canadian Yearbook, 2016, № 20, pp. 287-314.]

7. Кузнецова О.В. Региональная политика в Германии. География мирового развития. Сборник научных трудов. Москва, 2016, сс. 403-416. [Kuznecova O.V. Regional'naya politika v Germanii [Regional Policy in Germany] Geografiya mirovogo razvitiya $=$ Geography of global development, Moskva 2016, pp. 403-416.] 
8. Коломыц О.Н. Региональные инвестиционные проекты как инструмент преобразования механизмов управления региональным развитием. Международный научно-исследовательский журнал. 2016, №. 1, сc. 48-49. [Kolomyc O.N. Regional'nye investicionnye proekty kak instrument preobrazovaniya mekhanizmov upravleniya regional'nym razvitiem [Regional investment projects as a tool for transforming regional development management mechanisms] Mezhdunarodnyj nauchno-issledovatel'skij zhurnal = International research journal, 2016, №. 1, pp. 48-49.]

9. Гончарова Е.А. Управление региональными инвестиционными проектами на основе интеграционного подхода. Дисс. канд. экон. наук. Орел, 2005. 150 с. [Goncharova E.A. Upravlenie regional'nymi investicionnymi proektami na osnove integracionnogo podhoda. Diss. kand. ekon. nauk. [Management of regional investment projects based on an integration approach. Cand. Diss. (Econ.)]. Orel city, 2005. 150 p.]

10. Азжеурова К.Е. Инструментарий управления региональными инвестиционными проектами (на материалах Курской области). Дисс. канд. экон. наук. Курск, 2012. 170 c. [Azzheurova K.E. Instrumentarij upravleniya regional'nymi investicionnymi proektami (na materialah Kurskoj oblasti). Diss. kand. ekon. nauk. [Regional Investment Project Management Toolkit (on the materials of Kursk region). Cand. Diss. (Econ.)]. Kursk, 2012. 170 p.]

11. Малышев Д.П. Механизм управления региональными инвестиционными проектами. Дисс. канд. экон. наук. Великий Новгород, 2012. 193 с. [Malyshev D.P. Mekhanizm upravleniya regional'nymi investicionnymi proektami. Diss. kand. ekon. nauk. [Mechanism for managing regional investment projects. Cand. Diss. (Econ.)]. Veliky Novgorod, 2012. 193 p.]

12. Указ Президента Российской Федерации от 7 Мая 2018 года «О национальных целях и стратегических задачах развития Российской Федерации на период до 2024 года». [Ukaz Prezidenta Rossijskoj Federacii ot 7 Maya 2018 goda «O nacional'nyh celyah i strategicheskih zadachah razvitiya Rossijskoj Federacii na period do 2024 goda» [National goals and strategic objectives of the development of the Russian Federation for the period until 2024]] Available at: http://kremlin.ru/events/president/news/57425 (accessed 12.06.2020)

13. Стратегия пространственного развития Российской Федерации на период до 2025 года. Утверждена распоряжением Правительства Российской Федерации от 13 февраля 2019г. № 207-p. [Strategiya prostranstvennogo razvitiya Rossijskoj Federacii na period do 2025 goda [The spatial strategy of the Russian Federation for the period until 2025]] Available at: http://government.ru/docs/35733/ (accessed 10.06.2020)

14. Стратегия социально-экономического развития Дальнего Востока и Байкальского региона на период до 2025 года. Утверждена распоряжением Правительства Российской Федерации № 2094-р от 28 декабря 2009 г. [Strategiya social'noekonomicheskogo razvitiya Dal'nego Vostoka i Bajkal'skogo regiona na period do 2025 goda. [Strategy of socio-economic development of the Far East and the Baikal region for the period until 2025.]] Available at: http://government.ru/docs/33593/ (accessed 23.06.2020)

15. Постановление Правительства Российской Федерации № 308 от 15.04.2014 г. «Об утверждении государственной программы Российской Федерации «Социальноэкономическое развитие Дальневосточного федерального округа». [Postanovlenie Pravitel'stva Rossijskoj Federacii № 308 ot 15.04.2014 g. «Ob utverzhdenii gosudarstvennoj programmy Rossijskoj Federacii «Social'no-ekonomicheskoe razvitie Dal'nevostochnogo federal'nogo okruga». [State program of the Russian Federation «Socio-economic development of the Far East»]] Available at: http://government.ru/rugovclassifier/829/events/ (accessed 20.06.2020) 
16. Федеральный закон «О территориях опережающего социально-экономического развития в Российской Федерации» от 29.12.2014 № 473-Ф3. [Federal'nyj zakon «O territoriyah operezhayushchego social'no-ekonomicheskogo razvitiya v Rossijskoj Federacii» ot 29.12.2014 № 473-FZ. [Federal law “About territories of advanced social and economic development in the Russian Federation"]] Available at: http://kremlin.ru/acts/bank/39279 (accessed 13.06.2020)

17. Федеральный закон «О свободном порте Владивосток» от 13.07.2015 № 212-ФЗ. [Federal'nyj zakon «O svobodnom porte Vladivostok» ot 13.07.2015 № 212-FZ. [Federal Law "About the Vladivostok porto franco"]] Available at: http://pravo.gov.ru/proxy/ips/?docbody $=\&$ prevDoc $=102394548 \&$ backlink $=1 \& \&$ nd $=10$ 2376003 (accessed 13.06.2020)

18. Налоговый кодекс Российской Федерации. [Nalogovyj kodeks Rossijskoj Federacii [The tax code of the Russian Federation]] Available at: https://nalog.garant.ru/fns/nk/ (accessed 11.06.2020)

19. Постановление Правительства Российской Федерации от 15 октября 2014 г. № 1055 «Об утверждении методики отбора инвестиционных проектов, планируемых к реализации на территории Дальнего Востока». [ Postanovlenie Pravitel'stva Rossijskoj Federacii ot 15 oktyabrya 2014 g. № 1055 «Ob utverzhdenii metodiki otbora investicionnyh proektov, planiruemyh $\mathrm{k}$ realizacii na territorii Dal'nego Vostoka» [Approval of the methodology for selecting investment projects for implementation in the Far East]] Available at: http://pravo.gov.ru/proxy/ips/?docbody $=\&$ prevDoc $=102384620 \&$ backlink=1\&\&nd=10 2360331 (accessed 16.06.2020)

20. Меморандум об инвестиционной деятельности акционерного общества «Фонд развития Дальнего Востока и Байкальского региона» [Memorandum ob investicionnoj deyatel'nosti akcionernogo obshchestva «Fond razvitiya Dal'nego Vostoka i Bajkal'skogo regiona» [Memorandum of Investment Activities of the Joint-Stock Company "Development Fund of the Far East and the Baikal Region"]] Available at: https://www.fondvostok.ru/about/documents/_accessed 28.05.2020)

21. Постановление Правительства Российской Федерации № 1044 от 11 Октября 2014 г. «Об утверждении программы поддержки инвестиционных проектов, реализуемых на территории Российской Федерации на основе проектного финансирования» [Postanovlenie Pravitel'stva Rossijskoj Federacii № 1044 ot 11 Oktyabrya 2014 g. «Ob utverzhdenii programmy podderzhki investicionnyh proektov, realizuemyh na territorii Rossijskoj Federacii na osnove proektnogo finansirovaniya» [Approval of the investment project support program with project financing in the Russian Federation]] Available at: http://pravo.gov.ru/proxy/ips/?docbody $=\& n d=102359793$ (accessed 29.05.2020)

22. Федеральный закон от 25.02.1999 № 39-Ф3 «Об инвестиционной деятельности в Российской Федерации, осуществляемой в форме капитальных вложений» [Federal'nyj zakon ot 25.02.1999 № 39-FZ «Ob investicionnoj deyatel'nosti v Rossijskoj Federacii, osushchestvlyaemoj v forme kapital'nyh vlozhenij» [Federal Law "On Investment Activities in the Russian Federation"]] Available at: http://www.consultant.ru/document/cons_doc_LAW_22142/bb9e97fad9d14ac66df4b6e 67c453d1be3b77b4c/ (accessed 29.05.2020)

23. Свободный порт Владивосток. Протокол наблюдательного совета от 21 октября 2015 г. № 1. [Svobodnyj port Vladivostok. Protokol nablyudatel'nogo soveta ot 21 oktyabrya 2015 g. № 1. [Board minutes]] Available at: https://minvr.ru/activity/svobodnyy-port-vladivostok/pravovye-osnovy/ (accessed 01.06.2020) 
24. Корпорация развития Дальнего Востока. Реестр резидентов территорий опережающего социально-экономического развития [Korporaciya razvitiya Dal'nego Vostoka. Reestr rezidentov territorij operezhayushchego social'no-ekonomicheskogo razvitiya [Register of residents of territories of priority social and economic development]] Available at: https://erdc.ru/about-tor/ (accessed 01.06.2020)

\section{Сведения об авторе / About author}

Филатов Артемий Сергеевич, аспирант, кафедра национальной и региональной экономики, Российский экономический университет имени Г.В. Плеханова. 117997 Россия, г. Москва, Стремянный переулок, 36. ORCID ID: 0000-0003-2753-1509. E-mail: artemiy.filatov@gmail.com Artemiy S. Filatov, Postgraduate Student, Department of National and Regional Economics, Plekhanov Russian University of Economics. Stremyannyj pereulok, 36, Moscow, Russia 117997.

ORCID ID: 0000-0003-2753-1509. E-mail: artemiy.filatov@gmail.com 